\title{
ANALISIS BENTUK PENGABAIAN YANG DIALAMI LANSIA YANG TINGGAL BERSAMA KELUARGA
}

\author{
Ezalina $^{1} *$, Rizanda Machmud ${ }^{2}$, Nursyrwan Effendi ${ }^{3}$, Yantri Maputra ${ }^{4}$ \\ ${ }^{1}$ Program Studi S1 Keperawatan, STIKes Payung Negeri Pekanbaru. Jln Tamtama no 06 Lubuhbaru Timur Kec. \\ Payung Sekaki kota Pekanbaru Riau, Indonesia 28291 \\ ${ }^{2}$ Fakultas Kedokteran, Universitas Andalas Padang, komplek kampus unand, Limau Manis, Kec. Pauh, Kota \\ Padang, Sumatera Barat, Indonesia 25176 \\ ${ }^{3}$ Fakultas Ilmu Sosial dan Ilmu Politik, Universitas Andalas Padang, J1. Limau Manis, Limau Manis, Kec. Pauh, \\ Kota Padang, Sumatera Barat 25163 \\ ${ }^{4}$ Fakultas Kedokteran Psikologi, Universitas Andalas Padang. Jl. Limau Manis, Limau Manis, Kec. Pauh, Kota \\ Padang, Sumatera Barat 25163 \\ *ezalin44@gmail.com
}

\begin{abstract}
ABSTRAK
Meningkatnya jumlah lansia perlu diperhatikan pengasuhan yang diberikan oleh keluarga berupa pemenuhan kebutuhan fisik, pskologis, dan finansial sehingga lansia tidak terabaikan. Terdapat jenis pengabaian yang dialami lansia ketika tinggal bersama keluarga yaitu pengabaian fisik, psikologis, dan finansial.Tujuan penelitian ini adalah mengeksplorasi bentuk pengabaian yang dialami lansia berdasarkan pemenuhan kebutuhan fisik, psikologis, dan finansial. Jenis penelitian adalah kualitatif. Teknik sampling yang digunakan adalah purposive sampling dengan jumlah sampel 6 orang informan lansia. Analisis data menggunakan pendekatan analisis tematik. Hasil penelitian menunjukkan dari hasil wawancara dengan lansia didapatkan dalam pemenuhan kebutuhan fisik lansia tidak menjadi kewajiban anak, diberikan oleh anak jika anak menyanggupi, bantuan yang diberikan lansia dibayar secara gratis. Berdasarkan pemenuhan kebutuhan psikologis didapatkan lansia hanya sebagai objek, keluarga kurang peka dengan yang diinginkan lansia dan dalam pemenuhan kebutuhan finansial didapatkan pemenuhan keuangan lansia tidak rutin diberikan, lansia butuh uang untuk pegangan. Diharapkan pihak puskesmas melalui pemegang program lansia agar memberikan pedampingan kepada keluarga (care giver) dalam merawat lansia di rumah melalui keterlibatan kader.
\end{abstract}

Kata kunci: pengabaian, lansia, keluarga

\section{ANALYSIS OF THE NEGLECT TYPES EXPERIENCED BY THE ELDERLIES LIVING WITH THEIR FAMILY}

\begin{abstract}
The increasing number of elderly people leads to the need of giving attention on the care given by their families in terms of physical, psychological, and financial needs so they will not be neglected. There are three kinds of neglect experienced by them when living with their families, namely: physical, psychological, and financial neglects. This study aims to explore the neglect types experienced by the elderly based on the fulfillment of physical, psychological, and financial needs.This study used qualitative approach. The sampling technique used was purposive sampling with 6 elderly informants as the samples. Thematic analysis was used to analyze the data. Based on the results of interview, it was found that the physical need of the elderly is not their children's obligation, given if their children undertake it, the assistance provided by the elderly is considered free of charge. While, based on the psychological needs, the elderly is only as an object, their families is less sensitive to what the elderly wants. Then, in the financial needs, the elderly's financial fulfillment is not given routinely, the elderly need money to handle. It is expected that the Puskesmas (Community Health Center) through the holder of elderly program will provide assistance to the families (care givers) in caring for the elderly at home through the involvement of cadres.
\end{abstract}

Keywords: neglect, family, elderly

\section{PENDAHULUAN}

Saat ini jumlah penduduk lansia di Indonesia mencapai 22,6 juta atau $8,75 \%$ dari total penduduk (Kemenkes, 2017) . Tingginya populasi lansia menunjukkan saat ini Indonesia sedang menghadapi era penduduk berstruktur 
tua (ageing population) yang ditandai dengan risiko ketergantungan hidup yang melebihi $6 \%$ (Lestari, 2017) Permasalahan kesehatan yang muncul pada lansia berpacu dengan pertambahan jumlah lansia dan dengan meningkatnya umur harapan hidup memunkinkan lansia lebih lama berada di lingkungan keluarga (care giver). Hasil penelitian Maryam (Maryam, Rosidawati, Riasmini, \& Suryati, 2012) didapatkan keterampilan keluarga dalam merawat lansia dimana keluarga dengan pengetahuan kurang $47,8 \%$, keluarga dengan sikap kurang 48,3\%, dan keluarga dengan keterampilan kurang $49,8 \%$.

Meningkatnya pekerja usia produktif dan bergesernya pola keluarga dimana semakin banyaknya wanita yang bekerja di luar rumah sehingga wanita sebagai care giver merasa beban dalam merawat lansia. Penelitian oleh Maryam et al.,( 2012) tentang beban keluarga merawat lansia memicu penelantaran lansia dimana keluarga dengan beban tinggi sebanyak 105 orang $(52,2 \%)$. Hal ini membuat hidup lansia tidak potensial dan menjadi terlantar atau terabaikan.

Penelitian oleh Steinmentz tentang penganiayaan dan pengabaian lansia di keluarga yang dilakukan oleh anak didapatkan pengabaian psikologis yaitu $30 \%$ anak bicara kasar, 8,5\% mengancam untuk mengirim ke panti; pengababaian fisik yaitu $17 \%$ tidak memberikan makan dan pengobatan kepada lansia (Friedman, BBoden, \& Jones, 2010). Penelitian yang dilakukan oleh Sijuwade, (2008) didapatkan pengabaian fisik yaitu $48 \%$ keluarga tidak membawa lansia ke pelayanan kesehatan, 24\% keluarga tidak menolong lansia ketika mengeluhkan rasa letih, dan pengabaian finansial didapatkan 20\% keluarga tidak pernah menganggap serius soal keuangan yang dikeluhkan lansia. Perilaku pengabaian pada lansia dipicu oleh keterbatasan lansia dalam memenuhi kebutuhan hidup sehari-hari (Low, Yap, \& Brodaty, 2011).

Angka kejadian pengabaian lansia yang dilaporkan oleh National Center on Elder Abuse yaitu 1 dari 10 lansia yang berusia lebih dari 60 tahun di Amerika mengalami pengabaian. Dari 5 juta lansia yang mengalami pengabaian di Amerika didapatkan $90 \%$ pelaku adalah (NCOA, 2017). Penelitian oleh McDonald \& Thomas (2013) terhadap 267 lansia di Kanada didapatkan 24,4\% mengalami pengabaian sejak usia 55 tahun. Penelitian oleh
Bigala \& Ayiga (2014) pengabaian dan kekerasan pada lansia merupakan masalah kesehatan serius yang dialami lansia.

Data dari Badan Pusat Statistik (BPS) didapatkan lansia terlantar pada tahun 2012 yaitu sebesar $13,7 \%$ dan pada tahun 2014 meningkat meningkat menjadi $15 \%$ (BPS, 2015). Untuk kota Pekanbaru berdasarkan wawancara dengan salah satu petugas sosial di Panti Sosial Tresna Whreda Khusnul Khotimah Kota Pekanbaru didapatkan kondisi pengabaian lansia dalam keluarga merupakan salah satu pemicu yang menyebabkan lansia memilih tinggal di panti. Hal ini sesuai dengan hasil penelitian Miko (2017) didapatkan $40,79 \%$ lansia masuk panti karena terabaikan di rumah.

Dampak dari populasi lansia yang meningkat dan penelantaran lansia yaitu meningkatnya angka ketergantungan hidup (old depedency ratio) yaitu dari $12,2 \%$ pada tahun 2005 menjadi $13,3 \%$ pada tahun 2009 , dan saat ini meningkat menjadi 48,63\% (Kemenkes, 2017). Dampak fisik yang muncul pada lansia yang terabaikan adalah lansia mengalami gizi kurang 10\%-15\% (physical neglect) dan dampak psikologis adalah lansia mengalami depresi karena merasa kesepian jauh dari keluarga (Singh, Singh, Lall, \& Jain, 2013)

Upaya yang dilakukan pemerintah untuk sarana pelayanan sosial bagi lansia seperti sistem panti, pelayanan model pedampingan di kalangan keluarga (home care), dan pelayanan harian (day care) (Tanjung, Effendy, \& Wahyuni, 2019). Pendekatan non panti seperti Pusat Santunan Keluarga (Pusaka), posyandu lansia, kegiatan usia ekonomi produktif, Bina Keluarga Lansia (BKL) melalui ketahanan dan kesejahteraan keluarga dan program lansia tangguh melalui 7 dimensi yaitu fisik, sosial, spiritual, emosional, vokasional, lingkungan, dan intelektual.

Akan tetapi pada kenyataanya kehidupan lansia belum semuanya berada pada kehidupan sejahtera (BPS, 2015). Pelayanan panti jompo, pusat santunan lansia dan jaminan sosial baru terlaksana 6,6\%. Masih banyak lansia yang hidup di garis kemiskinan yaitu tempat tinggal yang tidak layak huni 5,51\%, lansia menderita sakit 25,5\% dengan tidak memiliki keluarga yang menyayangi dan merawat dengan baik (Sa'adah, 2015). Berdasarkan wawancara dengan salah satu petugas pemegang program BKL di BKKBN Kota Pekanbaru didapatkan program lansia tangguh belum tersosialisasi 
secara merata di keluarga, dari 14 keluarga yang sudah dibina, hanya $4,9 \%$ keluarga yang mengikuti kegiatan program BKL.

Penelitian ini penting dilakukan karena kasus pengabaian lansia di keluarga sulit diidentifikasi terkait budaya dan etika dimana lansia harus dihormati dan dihargai. Ketika terjadi pengabaian lansia di keluarga menyiratkan bahwa kelurga tidak menghormati dan menyia-nyiakan lansia. Adanya masalah ini perlu dilakukan pengamatan lebih dalam terhadap lansia melalui eksplorasi fenomena yang dialami partisipan yaitu lansia yang tinggal bersama keluarga di Kecamatan Payung Sekaki Kota Pekanbaru.

\section{METODE}

Jenis penelitian adalah kualitatif (Creswel, 2016). Teknik sampling purposive sampling dengan kriteria lansia berusia lebih atau sama dengan 60 tahun, tinggal bersana keluarga atau terpisah tapi masih dalam satu kota, pandai membaca dan menulis, dapat berkomunikasi efektif secara verbal dan dapat mendengar. Pengumpulan data informan melalui focus group discussion (FGD). Penelitian dilakukan dari bulan Agustus sampai Oktober 2018. Data yang didapat melalui verbatin wawancara dan catatan pengamatan (field note) lalu diubah dalam bentuk script melalui alur tema yang jelas (display data) (Hendiansyah, 2015). Untuk mengetahui keabsahan data dilakukan triangulasi sumber data melalui keluarga, kader, dan petugas kesehatan. Penelitian dlakukan setelah mendapat persetujuan dari lolos kaji etik (ethical clearance) dari Universitas Riau dengan Nomor: 150/UN.19.5.1.1.8/UEPKK/2018

\section{HASIL}

Berdasarkan hasil wawancara dengan lansia didapatkan bahwa dari segi pemenuhan kebutuhan fisik lebih banyak lansia yang tidak terabaikan dari pada yang terabaikan oleh keluarga. Bagi lansia ketika sudah tua semua kebutuhan bergantung kepada anak, baik itu kebutuhan makan, tempat tinggal, pemenuhan transportasi untuk bepergian dan pengobatan ketika sakit. Namun jika lansia masih bekerja dan fisik masih kuat, lansia juga tetap membantu kebutuhan anak, dan menjaga cucu ketika anak bekerja. Hal ini tidak masalah bagi lansia yang penting bagi lansia selama badan masih sehat dan masih bisa beraktifitas membantu anak tetap dilakukan dengan senang hati. Beberapa partisipan mengungkapkan hal tersebut sebagai berikut:
"Semua kebutuhan saya dan suami, anak yang memberikan...tak ada pemasukan dari suami, karena suami saya tak bisa ngapa-ngagapa lagi...tapi tak ada paksaan dari saya. kadang kalau mau bepergian harus dibicarakan dengan anak, karena cucu tidak bisa ditinggal, anak bekerja..." (P1)

'Alhamdulillah peninggalan suami masih ada, jadi tidak memberatkan kepada anak, tapi anak juga kadang memberi kebutuhan saya, tapi sedikitlah..."(P3)

"Ya penuhi sendiri, kami sama-sama cari, saya cari untuk saya dan istri, kadang juga membantu kebutuhan anak, bahkan menanggung cucu..." (P4)

“...anak kerja, kadang kerepotan juga menjalankan tugas rumah karena tidak ada yang bantu, tapi tak apalah ...." (P5, P6).

Untuk tema pengabaian psikologis umumnya lansia ingin diperhatikan, didengarkan nasehatnya, dan didengarkan keluhannya. Kadang kadang timbul juga rasa lelah di badan, sakit punggung, dan demam karena membantu keluarga dalam bersih-bersih rumah, menyapu, memasak, dan merawat cucu. Lansia Ingin sekali kalau keluhan yang dirasakannya di ketahui oleh anak sehingga lansia merasa diperhatikan. Lansia ingin sesibuk apapun hendaknya anak tetap ada perhatian untuk menanyakan keluhan yang dirasakan seperti pernyataan partisipan berikut: "Saya tidak mau mengeluh pada anak, dia sudah letih sangat sepulang kerja, jadi saya terima saja dengan segala yang terjadi pada saya, kalau letih saya istirahat saja dulu,sudah itu kerja lagi ngemas-ngemas rumah..." (P1,P2)

"Saya ingin ada kawan untuk bercerita,,,tapi ya itu tadi.saya paham anak-anak saya sibuk...saya ingin kalau anak-anak itu mengerti kalau orang tua sudah tua..."(P1,P2,)

"Anak dua orang tapi perhatiannya kurang...(mata berkaca-kaca)..,karna anak jauh susah untuk meminta perhatian.. ...(P5)

Beberapa partisipan juga mengungkapkan perasaan yang dirasakan ketika tinggal bersama anak:

“...hhhmmmm...ya itulah ada senang dan susah dalam keluarga, anak ada yang bikin 
ulah, menantu tidak mendengar kalau dinasehati, sedih tapi kadang diam aja, karena kalau dimasukkan ke hati nanti jadi kepikiran...(P4)

“..Nasehat adalah didengar sama anak, tapi susah juga, karena mereka ada yang jauh..jarang betemu...tapi kadang-kadang nasehat yang diberikan tidak juga di dengar..(P1.P2)

“...inginnya saat sedih anak-anak tau..diperhatikan, ditanya mamak ni, dibawa berobat,..." (P4,P5,P6).

Untuk tema pengabaian finansial lansia mengungkapkan dari segi keuangan umumnya lansia menerima berapapun jumlah uang yang diberikan oleh anak, kalau anak tidak sanggup memberikan uang bagi lansia hal tersebut tidak menjadi masalah, namun lansia lebih senang jika diberikan uang oleh anak sebagai pegangan atau untuk membeli sesuatu jika dibutuhkan. Hal tersebut diungkapkan oleh partisipan berikut:

"Untuk keuangan kita dah tua ni berapa dikasih anak je, kita tak minta, jika dikasi Alhamdulillah, dapatlah untuk bersedekah kalau ke mesjid atau nak membeli makanan $\ldots "(\mathrm{P} 2)$

“..Maunya dikasih uang jugalah..senang kalau dikasih uang oleh anak, walaupun sedikit..." $(\mathrm{P} 5, \mathrm{P} 6)$

\section{PEMBAHASAN}

Pengabaian adalah penolakan atau kegagalan untuk memberikan perawatan dan perlindungan, mengacuhkan, kurang empati, dan melalaikan pengasuhan kepada lansia baik dalam pemenuhan kebutuhan fisik, emosional, dan ekonomi Jika perlakuan pemenuhan kebutuhan lansia dilakukan sekali-sekali maka orang tidak akan menganggap anggota keluarganya mengabaikan orang tua, karena dipandang sebagai hal yng tidak sengaja. Namun jika semua kebutuhan tidak terpenuhi dilakukan berulang kali dan dalam jangka waktu yang panjang, maka akan memunculkan kesan pengabaian. Hal ini kemudian menimbulkan pikiran bahwa anggota keluarga (care giver) tidak menghargai kebutuhan orang tua (Sijuwade, 2008).

Hasil penelitian Alavi, et al (2011) hubungan antara anak-anak dewasa, orang tua, dan kakek nenek semakin melemah karena kesenjangan generasi yang menyebabkan konflik dan ketegangan dalam keluarga yang dapat membawa konsekuensi yang tidak sehat sehingga lansia yang sudah tidak lagi produktif terabaikan. Hampir semua lansia mengharapkan anak-anak mereka untuk merawat mereka saat sakit atau tidak bergerak dan takut jika dimasukkan dalam perawatan jangka panjang di rumah sakit atau panti jompo.

Hasil penelitian kualitatif didapatkan lansia ingin diperhatikan oleh anak, dan didengarkan keluhannya. Permasalahan yang dihadapi lansia lansia yang tidak tinggal serumah dengan anak yaitu kesibukan dari anakanaknya, tempat tinggal yang jauh sehingga anak jarang untuk mengunjungi, adanya konflik antara orang tua dengan anak dan anak tidak mau direpotkan dengan urusan orang tuanya serta orang tua sudah jarang dilibatkan dalam penyelesaian masalah. Hal ini menyebabkan lansia merasa tidak dibutuhkan lagi, tidak berguna, tidak dihargai dalam keluarga, dan merasa menjadi beban bagi keluarganya. Hal ini sejalan dengan penelitian yang dilakukan oleh (Samjana, 2017) bahwa orang tua di Nepal tidak menginginkan harapan yang tinggi, cukup sederhana yaitu agar anak-anak berusaha untuk mencoba memahami perasaan orang tua dan menunjukkan minat kearah tersebut. Orang tua tidak peduli jika anak belum mampu memberi makan dengan baik, pakaian yang tepat, semua yang diinginkan orang tua adalah anak cinta kepada orang tua, dan ketika orang tua tinggal bersama, orang tua disambut oleh keluarga (Punyakaew, Lersilp, \& Putthinoi, 2019).

Analisis penelitian kualitatif didapatkan lansia sangat senang jika diberikan uang oleh anak sebagai pegangan, dan anak menawarkan bantuan uang saat butuh pengobatan Hasil penelitian (Kaur, Kaur, \& Venkateashan, 2015) menunjukkan orang tua yang secara finansial tidak bergantung kepada orang lain memiliki kualitas hidup yang lebih baik dari pada mereka yang secara finansial tergantung kepada anggota keluarga mereka. Sehingga sebelum memasuki masa tua ada baiknya setiap individu untuk senantiasa menabung, mempunyai asuransi kesehatan, dan punya sedikit usaha sehingga ketika tua dapat menikmati apa yang sudah dipersiapkan sebelumnya. 


\section{SIMPULAN}

Perhatian anak sangat diharapkan dalam pemenuhan kebutuhan lansia. lansia tidak mengharap imbalan ketika harus merawat cucu dan mengurus rumah namun jangan sampai bantuan yang diberikan lansia dibayar secara gratis. Karena pada dasarnya lansia sangat senang jika diberi uang oleh anak walaupun sedikit. Dalam pemenuhan kebutuhan lansia perhatian anak sangat diharapkan, jangan jadikan lansia sebagai objek ketika tinggal bersama, dan cepat peka dengan apa yang dikeluhkan lansia sangat diharapkan oleh lansia.

\section{DAFTAR PUSTAKA}

Alavi, K., Sail, R. M., Idris, K., Samah, A. A., \& Omar, M. (2011). Living arrangement preference and family relationship expectation of elderly parents. Pertanika Journal of Social Science and Humanities, 19(SPEC. ISSUE), 65-73.

Bigala, P., \& Ayiga, N. (2014). Prevalence and predictors of elder abuse in mafikeng local municipality in South Africa. Etude de La Population Africaine, 28(1), 463-474. https://doi.org/10.11564/28-1-500

BPS. (2015). Statistik Penduduk Lanjut Usia. Badan Pusat Statistik.

Creswel, J. W. (2016). Research Design: pendekatan kualitatif, kuantitatif, dan campuran. Yogyakarta: Pustaka Pelajar.

Friedman, M., BBoden, V., \& Jones, E. (2010). Family Nursing, research, theory and practice No Title. New Jersey: Prentice Hill.

Hendiansyah. (2015). Metodologi penelitian kualitatif untuk ilmu psikologiNo Title. Jakarta: Salemba.

Kaur, H., Kaur, H., \& Venkateashan, M. (2015). Factors determining family support and quality of life of elderly population. International Journal of Medical Science and Public Health, 4(8), 1049. https://doi.org/10.5455/ijmsph.2015.210 12015220

Kemenkes. (2017). Analisis lansia di Indonesia. Pusat Data Dan Imformasi Kemenkes.

Lestari, M. D. (2017). Struktur keluarga di era Ageing Population. Buletin Konsorsium
Psikologi Ilmiah Nusantara, Vol 3 No 4.

Low, L. F., Yap, M., \& Brodaty, H. (2011). A systematic review of different models of home and community care services for older persons. BMC Health Services Research, 11(1), 93. https://doi.org/10.1186/1472-6963-1193

Maryam, R. S., Rosidawati, R., Riasmini, N. M., \& Suryati, E. S. (2012). Beban Keluarga Merawat Lansia Dapat Memicu Tindakan Kekerasan dan Penelantaran Terhadap Lansia. Jurnal Keperawatan Indonesia, 15(3), 143150. https://doi.org/10.7454/jki.v15i3.2

McDonald, L., \& Thomas, C. (2013). Elder abuse through a life course lens. International Psychogeriatrics, 25(8), 1235-1243.

Miko, A. (2017). Sosiologi Lansia, pergeseran pranata penyantunan lansia di Sumatera Barat. Padang: Erka.

National Center on Elder Abuse. (2017). Elder Abuse Research Review, September 2014-August 2017. 163(AUGUST), 877-878.

https://doi.org/10.2105/AJPH.2017.3038 $21 \mathrm{a}$

Punyakaew, A., Lersilp, S., \& Putthinoi, S. (2019). Active ageing level and time use of elderly persons in a Thai suburban community. Occupational Therapy International, 2019. https://doi.org/10.1155/2019/7092695

Sa'adah, N. (2015). Menata Kehidupan Lansia : Suatu Langkah Responsif untuk Kesejahteraan Keluarga ( Studi pada Lansia Desa Mojolegi Imogiri Bantul Yogyakarta). Jurnal Ilmiah Sosiologi Agama, 9(2), 49-70.

Samjana, T. (2017). Abandonment of Elderly People in. 1-40.

Sijuwade, P. O. (2008). Elderly Care by Family Members: Abandonment, Abuse and Neglect. The Social Sciences, Vol. 3, pp. 542-547. Retrieved from http://medwelljournals.com/abstract/?do isscience.2008.542.547

Singh, R., Singh, B., Lall, B., \& Jain, V. (2013). Psychosocial Problems: An Issue among the Elderly in Kathmandu, Nepal. International Journal of Health 
Science and Research, 3(5), 48-53.

Retrieved from

http://www.ejmanager.com/mnstemps/1 07/107-1375545537.pdf

Tanjung, R., Effendy, E., \& Wahyuni, S. E. (2019). Identifikasi social engagement pengaruhnya terhadap fungsi kognitif lansia di posyandu lanjut usia Kertapati Palembang tahun 2015. Journal of Islamic Nursing, 4(1), 26. https://doi.org/10.24252/join.v4i1.7903 